\title{
SOME MEDICAL-BIOLOGICAL ASPECTS AND ECOLOGICAL BACKGROUND DURING THE USAGE OF POISON CHEMICALS AGAINST THE PATHOGENESIS OF BUXUS COLCHICA
}

\author{
Giorgi Parulava, \\ professor, Georgian State Teaching University of Physical Education and Sport, Tbilisi, Georgia \\ DOI: https://doi.org/10.31435/rsglobal_conf/28022021/7431
}

\begin{abstract}
It is proved, that the unique model of Georgian flora, Colchian box-tree (Buxus), is in the phase of ecological catastrophe. The chance of survival is minimal in the refuges, gorges and mountain slopes. Relict or introductory plants of all Georgian box-tree species should be sprayed with pesticide "Dimelin" and tilled with fungicides. All types of Deltamethryn (Decis) pesticides must be removed from purging scheme, since, according to survey results, abovementioned drug is an ecological threat fot the human health and the fauna complexes.
\end{abstract}

Keywords. Ecology, metabolism, refugium, fauna complexes, pathogenesis, lethal.

Introduction. Buxus Colchica is member of Buxceae family and Buxus genus [6]. In the Georgian environmental conditions, there are two relict species - Buxus colchica and Buxus hyrcana; Introduced four species: Common or evergreen buxus (Buxus sempervorens), Balearic (Buxus balearica), Japanese buxus (Buxus japonica) and narrow leaf buxus (Buxus microphylla). Buxus is a special plant. Antic age authors frequently indicated to it, Old Roman poet Ovidius Naso mentioned that Goddess Athena made a flute form the buxus.

Buxus colchica is included in the red book of Georgia. It is also special plant for the Georgian flora. According to vertical distribution of the forest, it thrives in first, damp subtropical belt, till 350 meters above the sea level, as well as in second, mixed wide leafed Colchian type tree forest belt, located from 350 to 900 meters above the sea level. It feels itself especially good in the refugiums of Samagrelo region. It also must be noted that in the foothills of Samegrelo mountains and territories adjacent to the black sea beach belt, in the beginning of Pliocene, Colchian refugium of old Mesophilic forest flora relicts, plant refuge was formed, which was assisted by the formation of mountain slopes in a way that ensured the maintenance of warm and damp climate in some territories of Samegrelo. The remarkable example of it is the relict forest refugium of quaternary period across Khobistskali, near village Mukhuri of the Chkhorotsku region where Zelkova tree, Colchian ivy, sapwood, Caucasian bilberry, laurel, Pontic rhododendron, fig and forest dominant Buxus Colchica thrive next to each other [2]. It is evergreen bush or tree plant; It rises from 2 to 5 meters in height; Lives up to 600 years; Rises slowly, it starts its fructuousness in groves in bound forests from the age of 35 , but the sole growing plant - from the age of 15. It endures the trimming well, because of which it gets special decorative meaning. It has very hard and solid, because of which it is valuable in furniture making and ship building. From the ancient times, it was used as healing plant. It is also noteworthy that its leaves are poisonous and contains around 70 types of alkaloids, including cyclobuxine D. The whole amount of alkaloids in the plant is 3\%. Deadly dose of cyclobuxine D for warm blooded species during a peroral intake, on 1 kilogram per body mass, is $0.1 \mathrm{mg}$ [7].

Research results. Today, this wonderful piece of Georgian flora is under the threat of extinction. Environmental protection organizations assess the situation as an ecological catastrophe. Causes of this are the Buxus pathogens. Over the last 5 years, Buxus groves are being intensively desiccated. Expedition, which was held in Lugela ravine in 2010, spotted the massive damage of Buxus groves in the abovementioned refugiums, which expressed itself in stripping the plant from its leaves and intense development of moss on branches. Supposedly, it is caused by viruses. Initially, the plant roots are damaged. Root indumentums are being rotted, as a result of which the mixed mineral salts in water is not absorbed in the plant, which therefore cannot feed itself, process of photosynthesis is ceased and wilted leaves are falling down. Bark does crack on a stem, xylem gets black and starts 
rotting. This itself represents a wonderful substrate for a development of fungus and moss. Second one is the more dangerous disease - Buxus burn, which is caused by the Buxus fungus (Cylindrocladium buxicola) that is very famous in Europe. It has been vastly spread in decorative agriculture and is massively destroying Buxus plants. Brown spots are occurring on the leaves of an afflicted plant, leaves are consequently being discoloured, gets yellow and falls down [6]. Similar process repeats itself in second-third year. After this, branches are wilted first and then the whole tree does the same.

Besides this, the Cydalima perspectalis walker became the reason of wilting of the Buxus. Its homeland is the Eastern Asia. In Georgia, it was born in 2003, officially spotted in the Guria region, specifically in the territories of Shekvetili. It belongs to the Lepidoptera order and Crambidae family [5]. Despite that its biology and zoogeography is well studied, additional researches must be made in Georgian settings. Here it is must also be noted that said maleficent was not discovered in the refugiums. In the area of spreading, chemical fight against it gives good result, where pesticide Deltamethrin (Decis), whose toxicocinetics and toxicodynamics analyses show that the preparate in the process of metabolism creates many bioactive derivate, is widely used; Has clearly expressed hydrophobic characteristics and is easily absorbed to some specific molecules, which represent its main transport factor. Physical-chemical processes play important role in the dislocation of Decis (serum, supernatant), whose essence is aimed towards maintaining the constant level of current substance on the expense of depo-processes, which take place on the surface of erythrocyte-plasma division [3]. In addition to this, Decis is quickly degraded because of hydrolytes, oxidants, protolithic products and mixtures connected to them. Following types of complexes were discovered: transdeltamethrin, transhydroximetrol deltamethrin, 3-dibromovinil, 2,2-dimethylcyclo-propane and so on. There is also enough amount of remains, which are of ambiguous constitution (on the 35\% practical dose) Metabolism is different between animals and plants by mixture constitution. Quick release of Decis and its metabolism in animals is made with unimportant tendency of bioaccumulation [3]. Under the influence of Decis, on the skin of warm blooded, erythematic and dematic damage occurs after 1 hour and 49 minutes; Eye irritation, in particular eye blinding and cornea damage happened after 1 hour. Preparate showed short duration irritative effect with washing it off and not washing it off; with macroscopic and histologic observation, no trace of sensitivity was seen. Effect of meaning connected to rat reproduction try has not been caused in $3 \mathrm{~b}$ generation organic mass, small embryo toxic effect was being noticed as well as hard atyxia and partial degenerative changes of the spinal marrow, approximately $20 \%$ [1]. For the invertebrate animal fauna, any kind of contact with Decis is lethal, destructive for fauna complexes. Pesticide Dimelin, which is safe for human and warm blooded animals, is effective against the worms of Cydalima perspectalis walker. Bacterial origin biologic preparate Bacillus thuringiensis is greatly effective against the newly-born worms.

Mechanic method, which means a heavy trimming of plant, is widely used for protecting the Buxus from maleficent. In addition to this, it is also noteworthy that in the recreational zone, using chemical method against maleficent and diseases is strictly limited, that is why the orientation must be aimed toward the integrated method of fighting.

Far more complex situation is connected to the groves in the mountain slopes, ravines and refugiums, to where arrival with special technology is impossible. Land cultivation and fight against viruses is unimaginable.

Therefore, Colchian box-tree (Buxus Colchica) is on the verge of ecologic catastrophe, to save it, it is necessary for specialists of this field, scientific potential to unite, special program to form and to practically implement. The usage of deltamethrin and similar pesticides must be abolished in order to not be harmful for human health, especially on touristic routes. Enough supply of preparate Demilin must be imported, Buxus plants on places, where it is physically impossible to do so, must be immediately sprayed and worked with fungicides. It is proved with our research that the usage of any form of Decis is dangerous for human health and fauna complexes around it.

Conclusions. 1. Pesticide deltamethryn (Decis) must be removed from the means of fight against the pathogenesis of Colchian box-tree (Buxus colchica)

2. Deltamethryn (Decis) with its toxicokinetic and toxicodynamic indicators represents a dangerous poison chemical for the human health.

3. The usage of deltamethryn (Decis) in Buxus groves causes the change of fauna complexes in this ecological environment. 


\section{REFERENCES}

1. Zurabishvili Z., Parulava G., Shanidze L. - Biokinetics of Deltamethrin (Decis), 2009, Tbilisi, 11-13, 64

2. Parulava G. - Tourism in the Samegrelo-Zemo Svaneti Ecological Gamma, Tbilisi, Kirbisi, 2011, N7, 69-72

3. Parulava G. - Chronopharmacological Analysis of the Toxicodynamics and Toxicokinetics of the Deltamethrin and Amitriptyline, Tbilisi, 2010, 39.

4. Frisk H. - Lateinishes etymologishes worterbuch, Carl Winter's Universitats buchhandlung, 1960, 626

5. Mally R., Nuss M. - Phylogeny and nomenclature of the box tree moth, Cydolimaperspeqtalis (Walker, 2859) combine, which was recently introduced into Europe (Lepidoptera; Pyraloidea; Crambidae; Spilomelinae/ Eur. J. Entomology, 2010, \#107, 393-400.

6. Фасмер М. - Самшит, Етимологический словарь русского языка// М., 1986, “Наука”, 528

7. Retrieved from http//hnb.com/ua/articlos/s-zdorovie-samshit-vechnozelnyy-2473 